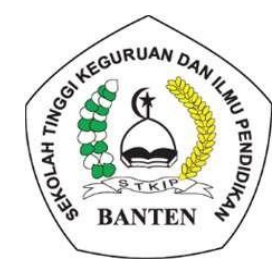

\title{
PERANAN MODEL PEMBELAJARAN KOOPERATIF TIPE PICTURE PICTURE TERHADAP KETERAMPILAN MENULIS PARAGRAF SISWA SD
}

\section{Ahmad Yanuar Syauki ${ }^{1}$, Destri Astrianingsih ${ }^{2}$, dan Nadiyya Khoiriyah ${ }^{3}$}

1Sekolah Tinggi Keguruan Dan Ilmu Pendidikan Banten

2Sekolah Tinggi Keguruan Dan Ilmu Pendidikan Banten

3Mahasiswa Pendidikan Guru Sekolah Dasar

Penulis Korepondensi: aysyauki@yahoo.com ${ }^{1 .}$ destriastria@gmail.com ${ }^{2}$,

nadiyyadhea29@gmail.com ${ }^{3}$

Artikel :

Model Pembelajaran Kooperatif Tipe Picture and Picture

Penerima: Juli 2021

Diterima: Agustus 2021

Dipublikasikan: September 2021

\begin{abstract}
The study aims to identify the role of the cooperative learning model type picture and picture of the writing paragraph skills of elementary students. This research is a qualitative literary methods. In this case studies take several journals or scripts that use the same methods. In this study, the researcher use four plots: Organized, synthesize, identify, and formulate. Data collection techniques with libraries and fragmentation. Whereas data analysis techniques use data reduction, data display, verification and conclusion. Related to the role of cooperative learning modelspicture and picture on the writing paragraph skills of elementary students. It has proven that there has been a fairly significant increase in the number of interviews conducted by previous studies with an average increase from the three referred journals pretest value $52.66 \%$ and increased to $86.11 \%$ on the postes' initial score with an average increase from previous research of $49.94 \%$. It turns out that using a picture and picture learning model can improve writing skills on elementary school children.
\end{abstract}

key words : Cooperative learning, picture and picture type, Writing paragraph skills.

\begin{abstract}
ABSTRAK
Penelitian ini bertujuan untuk mengetahui peranan model pembelajaran kooperatif tipe picture and picture terhadap keterampilan menulis paragraf siswa SD. Penelitian ini merupakan penelitian kualitatif metode literatur. Dalam hal ini penelitian mengambil beberapa jurnal atau skripsi yang menggunakan metode yang sama. Dalam penelitian ini menggunakan 4 alur yaitu: Organize, Synthesize, Identify, Formulate. Teknik pengumpulan data dengan pustaka dan dekomentasi. Sedangkan Teknik analisis data menggunakan reduksi data, display data, verifikasi dan kesimpulan. Yang berkaitan tentang Peranan Model Pembelajaran Kooperatif Tipe Picture And Picture Terhadap Keterampilan Menulis Paragraf Siswa SD.Terbukti telah terjadi peningkatan jumlah presentasi yang cukup signifikan pada setiap penelitian yangtelah dilaksanakan oleh penelitian sebelumnya dengan jumah rata-rata peningkatan dari tiga jurnal yangdirujuk yaitu nilai awal pretes 52,66\% dan meningkat menjadi $86,11 \%$ pada skor postes dengan rata- rata peningkatan dari peneliatian terdahulu yaitu $49,94 \%$. Ternyata dengan menggunakan model pembelajaran picture and picture dapat meningkatkan keterampilan menulis paragraf terhadap anak sekolah dasar.
\end{abstract}

Kata Kunci : Model pembelajaran, kooperatifi tipe picture and picture, keterampilan menulis paragraf. 
$2 \mid$ Ahmad Yanuar Syauki1, Destri Astrianingsih², Nadiyya Khoiriyah³, Peranan Model Pembelajaran Kooperatif Tipe Picture and Picture Terhadap Keterampilan Menulis Paragraf Siswa SD

\section{PENDAHULUAN}

Bahasa Indonesia sebagai salah satu mata pelajaran yang sering dimunculkan di semua jenis jenjang pendidikan. Mulai dari pendidikan dasar, menengah, hingga pendidikan yang lebih tinggi memegang peranan penting dalam upaya peningkatan mutu pendidikan. Khususnya di sekolah dasar, pelajaran bahasa Indonesia sangatlah penting untuk lebih ditekankan karena dalam pelajaraan bahasa Indonesia terkandung berbagai keterampilan dasar yang patut dimiliki siswa agar dapat mengembangkan diri pada jenjang pendidikan yang lebih tinggi. Mata pelajaran bahasa Indonesiauntuk menciptakan suasana baru dalam pembelajaran membaca. Suasana dan cara baru itu diharapkan mampu meningkatkan semangat belajar dan keterampilan membaca siswa. ${ }^{1}$

Mengingat betapa pentingnya pelajaran Bahasa Indonesia bagi kita, maka saya akan memfokuskan pembahasan skripsi saya pada pelajaran Bahasa Indonesia di sekolah dasar. Kenapa memilih di sekolah dasar? Karena di fase anak usia dini inilah mereka akan lebih mudah mencerna dan memahami dasar-dasar keterampilan yang ada pada pelajaran Bahasa Indonesia.Apabila dari usia dini saja siswa sudah mampu memahami dan mempraktikkan dasar-dasar keterampilan yang ada pada pelajaran Bahasa Indonesia, maka kedepannya ketika mereka sudah memasuki jenjang pendidikan yang lebih tinggi, mereka

\footnotetext{
${ }^{1}$ Widianto, Peningkatan Keterampilan Membaca Teks Klasifikasi Menggunakan Metode Sq3r Dengan Media Gambar. (Jurnal Pendidikan Bahasa dan Sastra Indonesia, 2015)
}

akan lebih mudah untuk memahami pelajaran Bahasa Indonesia di tingkat selanjutnya.

Pembelajaran bahasa yang utama adalah sebagai alat komunikasi. Seorang anak belajar bahasa karena didesak oleh kebutuhan untuk berkomunikasi dengan orang-orang di lingkungan sekitar. Manusia adalah makhluk sosial, sehingga manusia perlu berinteraksi dengan manusia lainnya. Pada saat manusia membutuhkan eksistensinya, maka interaksi itu terasa semakin penting. Kegiatan berinteraksi ini membutuhkan alat, sarana atau media, yaitu bahasa. Sejak itulah bahasa menjadi alat, sarana atau media. ${ }^{2}$

Bahasa merupakan alat komunikasi masyarakat, pentingnya bahasa dalam masyarakat dapat terbukti dalam komunikasi kehidupan sehari-hari dan teknologi sekarang ini, bahasa mempunyai peran yang sangat penting dalam bentuk komunikasi lisan maupun tulis, seseorang dikatakan mampu berbahasa apabila seseorang tersebut mampu menggunakan bahasa tersebut, baik secara lisan maupun tulis.

Pembelajaran di Indonesia, terutama di sekolah dasar tidak akan terlepas dari empat aspek keterampilan berbahasa berdasarkan kurikulum, yaitu (1) menyimak, (2) berbicara, (3) membaca, dan (4) menulis. Hal ini menunjukkan bahwa empat aspek tersebut sangat berperan penting dalam pengajaran suatu bahasa di sekolah. Dari

\footnotetext{
2 Depdiknas, Sistem Pendidikan Nasional. (Jakarta: Depdiknas, 2009) HIm. 1-3
} 
keempat aspek ini disebutkan salah satunya adalah keterampilan menulis. ${ }^{3}$

Tarigan menjelaskan bahwa "menulis merupakan suatu keterampilan berbahasa yang di pergunakan untuk berkomunikasi secara tidak langsung, tidak secara tatap muka dengan orang lain. Menulis merupakan kegiatan yang produktif dan ekspresif." 4

Berdasarkan pemaparan diatas, maka saya akan memfokuskan pembahasan pada keterampilan menulis paragraf siswa. Keterampilan menulis paragraf itu sangat penting, karena merupakan salah satu keterampilan berbahasa yang harus dimiliki oleh siswa. Dengan menulis, siswa dapat mengungkapkan atau mengekspresikan gagasan atau pendapat, pemikiran, dan perasaan yang dimiliki. Selain itu dapat mengembangkan daya pikir dan kreativitas siswa dalam menulis paragraf.

Keterampilan menulis paragraf perlu ditananamkan kepada siswa Sekolah Dasar. Dengan memiliki kemampuan menulis, cakrawala berpikir kreatif dan kritis siswa dapat berkembang dan dapat mempertajam kepekaan perasaan, penalaran, serta kepekaan anak terhadap masalah kemanusiaan. Kemampuan tersebut ditentukan oleh beberapa faktor yang penting dalam proses pembelajaran menulis paragraf.

Kegiatan pembelajaran bahasa tidak akan pernah lepas dari kegiatan menulis.

\footnotetext{
${ }^{3}$ Susanto, Teori Belajar dan Pembelajaran di Sekolah Dasar. (Jakarta: Prenadamedia Group, 2013) HIm.

Setelah memikirkan ide dan gagasan, siswa menuangkannya dalam bentuk tulisan. Tulisan inilah yang akan menjadi cerminan ide dan gagasan siswa. Semakin baik tulisan yang dibuat oleh siswa, maka semakin baik pula ide dan gagasan yang dimiliki. ${ }^{5}$ Namun, meskipun telah disadari bahwa penguasaan bahasa tulis mutlak dalam pendidikan dan kehidupan, tetapi dalam kenyataannya, pengajaran keterampilan menulis paragraf kurang mendapat perhatian. Anggapan yang keliru bahwasanya, siswa dikatakan pintar/pandai jika bisa dan menguasai pelajaran eksak, sedangkan kegiatan menulis paragraf dipandang sebelah mata.

Hal ini menyebabkan mata pelajaran yang idealnya menarik dan besar sekali manfaatnya bagi siswa disajikan hanya sekedar memenuhi tuntutan kurikulum. Padahal, bila disajikan secara mendalam, tujuan pengajaran bahasa dan sastra indoneisa di sekolah dimaksudkan untuk menumbuhkan keterampilan, rasa cinta, dan penghargaan para siswa terhadap bahasa dan sastra Indonesia sebagai bagian dari budaya warisan leluhur. Karena pada dasarnya, semua pengetahuan, tanggapan, dan pendapat dituangkan salah satunya dalambentuk tulisan paragraf. Oleh karena itu, pembelajaran keterampilan menulis paragrafperlu dikelola dengan cara memberikankesempatan kepada siswa untuk berlatih secara produktif.

\footnotetext{
${ }^{5}$ Miftahul, Meningkatkan Keterampilan Menulis Karangan Narasi Melalui Model Pwin (Picture Word Inductive Model) Siswa Kelas IVB SD Negeri Ketib Kecamatan Sumedang Utara Kabupaten Sumedang. (Jurnal Pena Ilmiah: Vol.2, No 1 2017)
} 
4|Ahmad Yanuar Syauki1, Destri Astrianingsih², Nadiyya Khoiriyah³, Peranan Model Pembelajaran Kooperatif Tipe Picture and Picture Terhadap Keterampilan Menulis Paragraf Siswa SD

Pembelajaran yang baik perlu ditunjang dengan beberapa faktor, yaitu materi, model pembelajaran, media, serta sarana dan prasarana. Guru perlu menggunakan suatu model pembelajaran untuk dapat memotivasi agar lebih kreatif. Seorang guru harus memiliki keterampilan dalam memilih, memanfaatkan, dan menggunakan model pembelajaran yang inovatif, sederhana, serta dapat merangsang minat siswa dalam belajar. Penggunaan model pembelajaran merupakan faktor yang tidak kalah penting untuk meningkatkan motivasi belajar siswa. Selama ini, guru kurang memanfaatkan model pembelajaran yang tepat bagi siswa. Model pembelajaran yang tepat juga dapat membantu untuk mewujudkan situasi belajar yang efektif.

Hamalik mengemukakan bahwa pemakaian media pembelajaran dalam proses belajar mengajar dapat membangkitkan keinginan dan minat yang baru, membangkitkan motivasi dan rangsangan kegiatan belajar, dan bahkan membawa pengaruh-pengaruh psikologis terhadap siswa. ${ }^{6}$

Banyak faktor yang menjadi penyebab redahnya kualitas tulisan siswa dan keterampilan menulis paragraf siswa, di antaranya: Guru cenderung menggunakan metode yang monoton dalam pembelajaran. Sehingga membuat siswa jenuh dan kurang mendapatkan variasi model pembelajaran. Selanjutnya, model pembelajaran yang digunakan oleh guru masih bersifat Teacher Centered (berpusat pada guru). Jadi, siswa kurang diberikan ruang dan waktu untuk mereka mengeksplor dirinya ketika proses pembelajaran berlangsung. Hal ini menyebabkan siswa kurang aktif dalam proses pembelajaran dan menyebabkan rendahnya kemampuan siswa dalam menulis paragraf, sehingga hasil belajar siswa pun kurang memuaskan. Selain karena beberapa faktor di atas, ada hal lain yang menyebabkan rendahnya kualitas tulisan paragraf siswa, yakni fasilitas media yang kurang memadai.

Suatu bangsa dapat dikatakan maju atau tidak hal tersebut dapat diamati melalui sistem pendidikannya. Pendidikan yang baik dapat berpengaruh tarhadap kualitas sumber daya manusia yang mumpuni serta menjadi suatu wadah kualitas penentu bangsa itu sendiri. Agar suatu pendidikan dapat dikatakan baik dan berkualitas, pendidik sebagai tokoh yang mengemban peranan penting tersebut harus turut berkualitas. Kunci utama dari pendidikan terletak pada pendidik yang mampu mengemban tugasnya secara profesional guna menyalurkan pendidikan yang sesuai dan terarah agar tujuan dari sistem pendidikan nasional tersebut dapat tercapai sepenuhnya.

Pendidik yang baik tentunya diharapkan dapat menggunakan modelmodel pembelajaran yang tepat. Modelmodel pembelajaran tersebutlah yang menentukan apakah pembelajaran akan berlangsung dengan baik dan berujung pada tercapainya kompetensi yang diinginkan atau sebaliknya.

\footnotetext{
${ }^{6}$ Prof. Dr. Azhar Arsyad, M.A. Media Pembelajaran, (Jakarta, Rajawali Pres, Tahun 2017) HIm.19 
5 Ahmad Yanuar Syauki1, Destri Astrianingsih², Nadiyya Khoiriyah³, Peranan Model Pembelajaran Kooperatif Tipe Picture and Picture Terhadap Keterampilan Menulis Paragraf Siswa SD

Pembelajaran merupakan sebuah dialog yang terjadi antara pendidik dan peserta didik yang didalamnya terdapat sebuah proses transfer ilmu. Dari proses tersebut pada akhir nanti peserta didik akan memperoleh hasil belajar yang telah ditempuh selama mereka melakukan pembelajaran. $^{7}$

Berkenaan dengan pendidik yang profesional, pemerintah juga diharapkan sepatutnya untuk mendukung proses dari pembangunan pendidikan yang ada. Pembaharuan di dalam kurikulum pendidikan yang selama ini dilakukan oleh pemerintah di harapkan dapat terus menyempurnakan perangkat pembelajaran yang memiliki standar sesuai dengan tujuan dari sistem pendidikan. Saat ini kurikulum 2013 digunakan sebagai pembaharuan kurikulum sebelumnya, KTSP. Kurikulum 2013 diharapkan dapat mampu mengisi kekurangan-kekurangan yang ada di dalam kurikulum KTSP. Lahirnya Kurikulum 2013 diharapkan mampu untuk mempersiapkan manusia Indonesia agar memiliki kemampuan hidup sebagai pribadi dan warga negara yang beriman, produktif, kreatif, inovatif, dan efektif serta mampu berkontribusi pada kehidupan masyarakat, berbangsa, bernegara, dan peradaban dunia. ${ }^{8}$

Penggunaan dan pemanfaatan model pembelajaran Kooperatif tipe Picture and Picture diharapkan dapat berpengaruh terhadap keterampilan menulis paragraf,

\footnotetext{
${ }^{7}$ Suprijono, Agus. Metode Dan Model-model Mengajar (Bandung, Alfabeta , 2012) HIm. 13

${ }^{8}$ Permendikbud. Kurikulum 2013 No. 67 thn 2013. HIm. 4
}

khususnya di tingkat Sekolah Dasar (SD). Model pembelajaran Kooperatif tipe Picture and Picture pada dasarnya, siswa dituntut untuk aktif dalam proses pembelajaran menulis paragraf. Dengan demikian, dalam model pembelajaran ini siswa dibebaskan untuk menulis "apapun" sesuai dengan apa yang dilihat dan yang dipahami.

Berdasarkan uraian di atas, penulis mencoba melakukan penelitian untuk pembuatan skripsi dengan judul "Peranan Model Pembelajaran Kooperatif Tipe Picture and Picture Terhadap Keterampilan Menulis Paragraf Siswa SD."

\section{LANDASAN TEORI}

\section{Model Pembelajaran Kooperatif}

Pembelajaran koopetarif merupakan model pembelajaran dengan menggunakan sistem pengelompokkan/tim kecil yaitu antara empat sampai enam orang yang mempunyai latar belakang kemampuan akademik, jenis kelamin, ras, atau suku yang berbeda (heterogen). Sistem penilaian dilakukan terhadap kelompok. Setiap akan memperoleh penghargaan (reward), jika kelompok mampu menunjukkan prestasi yang dipersyaratkan. Dengan demikian, setiap anggota kelompok akan mempunyai ketergantungan positif. ${ }^{9}$

Ketergantungan semacam itulah yang selanjutnya akan memunculkan tanggung jawab individu terhadap kelompok dan

\footnotetext{
${ }^{9}$ Wina Sanjaya, strategi pembelajaran berorentasi standar proses Pendidikan, (Jakarta:kencana perdana media grup, 2008) cet. 5 hal. 242
} 
6|Ahmad Yanuar Syauki1, Destri Astrianingsih², Nadiyya Khoiriyah³, Peranan Model Pembelajaran Kooperatif Tipe Picture and Picture Terhadap Keterampilan Menulis Paragraf Siswa SD

keterampilan interpersonal dari setiap anggota kelompok. Setiap individu akan saling membantu, sehingga setiap individu akan memiliki kesempatan yang sama untuk memberikan kontribusi demi keberhasilan kelompok. ${ }^{10}$

\section{Dalam model pembelajaran} kooperatif ini, guru lebih berperan sabagai fasilitator yang berfungsi sebagai jembatan penghubung ke arah pemahaman yang lebih tinggi, dengan catatan siswa sendiri. Guru tidak hanya memberikan pengetahuan pengetahuan pada siswa, tetapi juga harus membangun pengetahuan dalam pikirannya. Siswa mempunyai kesempatan untuk mendapatkan pengalaman langsung dalam menerapkan ide-ide meraka, ini merupakan kesempatan bagi siswa untuk menemukan dan menerapkan ide-ide mereka sendiri. ${ }^{11}$

Berdasarkn paparan para penulis di atas, dapat disimpulkan bahwa pembelajaran kooperatif adalah strategi pembelajaran yang didalamnya melibatkan siswa untuk saling bekerjasama dan saling membantu untuk menyelesaikan tugas akademik dan dapat membangun hubungan sosial sesama siswa. Karena adanya saling interaksi di dalam strategi pembelajaran tersebut. Dan dapat membangun motivasi untuk sama-sama meraih kesuksesan.

\section{a. Konsep Dasar Pembelajaran Kooperatif}

\footnotetext{
${ }^{10}$ Wina Sanjaya, strategi pembelajaran berorentasi standar proses Pendidikan, (Jakarta:kencana perdana media grup, 2008) cet. 5 hal. 242-243

${ }^{11}$ Rusman, model-model pembelajaran mengembangkan profesionalisme guru, (jakarata:PT. raja grafindo, persada, 2013), cet. 6 ha. 202.
}

Pembelajaran kooperatif (cooperative learning) merupakan bentuk pembelajaran dengan cara siswa belajar dan bekerja dalam kelompok-kelompok kecil secara kolaboratif yang anggotanya terdiri empat sampai enam orang dengan struktur kelompok yang bersifat heterogen. ${ }^{12}$

Pada hakikatnya cooperative learning sama dengan kerja kelompok. Oleh karena itu, banyak guru yang mengatakan tidak ada sesuatu yang aneh dalam cooperative learning karena mereka beranggapan telah biasa melakukan pembelajaran cooperative learning dalam bentuk belajar kelompok. Walaupun sebenarnya tidak semua belajar kelompok dikatakan cooperative learning, seperti dijelaskan Abdulhak bahwa "Pembelajaran cooperative dilaksanakan melalui sharing proses antara peserta belajar, sehingga dapat mewujudkan pemahaman bersama di antara peserta belajar itu sendiri". ${ }^{13}$

\section{b. Tujuan Pembelajaran Kooperatif}

Tujuan pembelajaran kooperatif adalah Yang pertama; dapat meningkatkan hasil belajar akademik. Karena dengan model pembelajaran kooperatif ini, siswa akan lebih termotivasi dalam belajar dan dapat terhindar dari rasa jenuh ketika proses KBM berlangsung. Yang kedua; siswa akan belajar untuk saling menerima perbedaan berdasarkan ras, budaya, kelas sosial, kemampuan, dan ketidakmampuannya,

\footnotetext{
12 Rusman, Model-Model Pembelajaran Mengembangkan Profesionalisme Guru, (Jakarta: PT. Raja Grafindo Persada, 2013), Cet. VI. h. 202

13 Ibid, h. 203.
} 
7 Ahmad Yanuar Syauki1, Destri Astrianingsih², Nadiyya Khoiriyah³, Peranan Model Pembelajaran Kooperatif Tipe Picture and Picture Terhadap Keterampilan Menulis Paragraf Siswa SD

sehingga dapat membentuk pribadi yang berjiwa sosial dan saling tolong menolong untuk meraih kesuksesan bersama.

Dan yang selanjutnya pengembangan keterampilan sosial. Dangan adanya pembelajaran kooperatif, siswa akan diajarkan untuk bisa saling bekerja sama dan saling membantu apabila ada anggota belajarnya yang masih belum memahami terkait pelajaran yang sedang berlangsung. Sehingga dapat membentuk pribadi sosial yang tinggi dan saling tolong menolong dalam kebaikan.

\section{c. Langkah-langkah Pembelajaran Kooperatif}

Terdapat enam langkah utama atau tahapan di dalam pelajaran yang menggunakan pembelajaran kooperatif. ${ }^{14}$

Langkah-langkah Pembelajaran Kooperatif

\begin{tabular}{|c|c|}
\hline Fase & $\begin{array}{l}\text { Tingkah Laku } \\
\text { Guru }\end{array}$ \\
\hline $\begin{array}{l}\text { Fase-1 } \\
\qquad \begin{array}{l}\text { Menyampaikan } \\
\text { tujuan dan } \\
\text { memotivasi } \\
\text { siswa }\end{array}\end{array}$ & $\begin{array}{l}\text { Guru } \\
\text { menyampaikan } \\
\text { semua tujuan } \\
\text { pelajaran yang } \\
\text { ingin dicapai } \\
\text { pada pelajaran } \\
\text { tersebut dan } \\
\text { memotivasi } \\
\text { siswa belajar. }\end{array}$ \\
\hline Fase-2 & $\begin{array}{l}\text { Guru } \\
\text { menyajikan }\end{array}$ \\
\hline
\end{tabular}

${ }^{14}$ Trianto, Mendesain Model Pembelajaran InovatifProgresif. Konsep, Landasan dan Implementasinya pada Kurikulum Tingkat Satuan Pendidikan (KTSP),

\begin{tabular}{|c|c|}
\hline $\begin{array}{l}\text { Menyajikan } \\
\text { informasi }\end{array}$ & $\begin{array}{l}\text { informasi } \\
\text { kepada siswa } \\
\text { dengan jalan } \\
\text { demonstrasi } \\
\text { atau lewat } \\
\text { bahan bacaan. }\end{array}$ \\
\hline $\begin{array}{l}\text { Fase-3 } \\
\text { Mengorganisasi } \\
\text { kan siswa ke } \\
\text { dalam } \\
\text { kelompok } \\
\text { kooperatif }\end{array}$ & $\begin{array}{l}\text { Guru } \\
\text { menjelaskan } \\
\text { kepada siswa } \\
\text { bagaimana } \\
\text { caranya } \\
\text { membentuk } \\
\text { kelompok } \\
\text { belajar dan } \\
\text { membantu } \\
\text { setiap kelompok } \\
\text { agar melakukan } \\
\text { transisi secara } \\
\text { efisien. }\end{array}$ \\
\hline $\begin{array}{l}\text { Fase } 4 \\
\text { Membembing } \\
\text { kelompok } \\
\text { bekerja dan } \\
\text { belajar }\end{array}$ & $\begin{array}{l}\text { Guru } \\
\text { membimbing } \\
\text { kelompok- } \\
\text { kelompok } \\
\text { belajar pada saat } \\
\text { mereka } \\
\text { mengerjakan } \\
\text { tugas mereka. }\end{array}$ \\
\hline $\begin{array}{l}\text { Fase } 5 \\
\quad \text { Evaluasi }\end{array}$ & $\begin{array}{l}\text { Guru } \\
\text { mengevaluasi } \\
\text { hasil belajar } \\
\text { tentang materi } \\
\text { yang telah } \\
\text { dipelajari atau } \\
\text { masing-masing } \\
\text { kelompok } \\
\text { mempresentasik }\end{array}$ \\
\hline
\end{tabular}

(Jakarta: Kharisma Putra Utama, 2017), Cet. 3, h. 117. 
$8 \mid$ Ahmad Yanuar Syauki, Destri Astrianingsih², Nadiyya Khoiriyah³, Peranan Model Pembelajaran Kooperatif Tipe Picture and Picture Terhadap Keterampilan Menulis Paragraf Siswa SD

\begin{tabular}{|c|l|}
\hline & $\begin{array}{l}\text { an hasil } \\
\text { kerjanya. }\end{array}$ \\
\hline Fase 6 & Guru mencari \\
penghargaan & cara-cara untuk \\
menghargai \\
& baik upaya \\
& maupun hasil \\
& belajar individu \\
& dan kelompok. \\
\hline
\end{tabular}

\section{d. Karakteristik Model Pembelajaran Kooperatif}

Pembelajaran kooperatif dapat dijelaskan dalam beberapa perspektif, yaitu:

1) Perspektif motivasi artinya penghargaan yang diberikan kepada kelompok yang dalam kegiatannya saling membantu untuk memperjuangkan keberhasilan kelompok.

2) Perspektif sosial artinya melalui kooperatif setiap siswa akan saling membantu dalam belajar karena mereka menginginkan semua anggota kelompok memperoleh keberhasilan.

3) Perspektif perkembangan kognitif artinya dengan adanya interaksi antara anggota kelompok dapat mengembangkan prestasi siswa untuk berpikir mengolah berbagai informasi. ${ }^{15}$

\section{Model Pembelajaran Picture and Picture}

${ }^{15}$ Rusman, Model-Model Pembelajaran Mengembangkan Profesionalisme, (Jakarta: PT. Raja Grafindo Persada, 2013), Cet. 6, h. 206-207.

\section{a. Pengertian Model Pembelajaran Picture and Picture}

Menurut Marsudi model pembelajaran picture and picture adalah suatu model belajar yang menggunakan gambar dan dipasangkan/diurutkan menjadi urutan logis. Model pembelajaran ini mengandalkan gambar sebagai media dalam proses pembelajaran. Gambar-gambar ini menjadi faktor utama dalam proses pembelajaran. Sehingga sebelum proses pembelajaran guru sudah menyiapkan gambar yang akan ditampilkan baik dalam bentuk kartu atau dalam bentuk carta dalam ukuran besar. ${ }^{16}$

Salah satu tipe yang ditawarkan pembelajaran kooperatif adalah pembelajaran tipe picture and picture. Menurut Suprijono, Picture and Picture merupakan strategi pembelajaran yang menggunakan gambar sebagai media pembelajaran. ${ }^{17}$

Strategi ini mirip Example non Example, digambar yang diberikan kepada siswa harus dipasangkan atau diurutkan secara logis. Gambar-gambar ini menjadi perangkat utama dalam pembelajaran. Untuk itulah, sebelum proses pembelajaran berlangsung, guru sudah menyiapkan gambar yang akan ditampilkan baik dalam bentuk kartu atau dalam bentuk carta berukuran besar. Gambar-gambar tersebut juga bias

\footnotetext{
${ }^{16}$ Moch. Agus Krisno Budiyanto, Sintaks 45 Model Pembelajaran, (Malang, Universitas Muhammadiah Malang 2019) HIm.119

17 Ibid , HIm.236
} 
9|Ahmad Yanuar Syauki1, Destri Astrianingsih², Nadiyya Khoiriyah³, Peranan Model Pembelajaran Kooperatif Tipe Picture and Picture Terhadap Keterampilan Menulis Paragraf Siswa SD

ditampilkan melalui bantuan power point atau software-software lain. ${ }^{18}$

\section{b. Langkah-Langkah \\ Model Pembelajaran Picture and Picture}

1. Guru menyampaikan kompetensi yang ingin dicapai.

2. Menyajikan materi sebagai pengantar.

3. Guru menunjukkan atau memperhatikan gambar-gambar kegiatan yang berkaitan dengan materi.

4. Guru dalam menentukan akan menunjuk atau memanggil siswa secara bergantian untuk memasang atau mengurutkan gambar-gambar menjadi urutan yanglogis.

5. Guru menanyakan alasan atau dasar pemikiran dari urutan gambar tersebut.

6. Dari alasan atau urutan gambar tersebut, guru mulai menanamkan konsep atau materi, sesuai dengan kompetensi yang ingin dicapai.

7. Siswa diajak untuk menyimpulkan atau merangkum materi yang baru saja diterimanya. ${ }^{19}$

\section{METODOLOGI PENELITIAN}

Jenis penelitian ini peneliti menggunakan studi Literatur yaitu mengumpulkan data atau karya tulis ilmiah yang berkaitan dengan objek penelitian atau pengumpulan data yang bersifat kepustakaan, atau telaah yang dilaksanakan untuk memecahkan masalah yang pada dasarnya

${ }^{18}$ Miftahul Huda, Model-Model Pengajaran dan Pembelajaran, (Yogyakarta: Pustaka Pelajar, 2014) HIm. 236

${ }^{19}$ Moch. Agus Krisno Budiyanto, Sintaks 45 Model Pembelajaran, (Malang, Universitas Muhammadiah Malang 2019) HIm.120 tertumpu pada penelaah kritis dan mendalam terhadap bahan-bahan pustaka yang relevan.

Menurut Suarifqi Diantama studi Literatur dilakukan dengan cara mempelajari dan mengkaji buku-buku atau sumber informasi tentang masalah yang diteliti, teknik ini selain digunakan untuk melengkapi serta memperkuat hasil penelitian yang dilakukan, teknik ini dilakukan dengan cara mengumpulkan berbagai macam sumber dan literatur buku-buku yang berkaitan dengan masalah yang sedang diteliti. ${ }^{20}$

Dalam penelitian ini pendekatan yang dilakukan adalah melalui pendekatan kualitatif, artinya data yang dikumpulkan bukan berupa angka-angka, melainkan data tersebut dari kajian kepustakaan.

Peneliti dalam penelitian ini mengumpulkan data dari berbagai sumber yaitu dari buku-buku terkait, abstrak penelitian yang relevan, serta jurnal ilmiah yang berkaitan dengan judul penelitian ini yaitu menggunakan model pembelajaran kooperatif tipe picture and picture terhadap keterampilan menulis paragraf siswa di SD.

Dalam penelitian ini peneliti membuat empat alur yang digunakan dalam penelitian ini. Empat alur tersebut yaitu :

1. Organize, yaitu mengorganisasi literatur yang akan ditinjau atau dilihat. Literatur yang akan ditinjau merupakan literatur yang relevan atau sesuai dengan permasalahan. Adapun tahapan dalam

\footnotetext{
${ }^{20}$ Suarifqi Diantama M.Pd, Metode Penelitian Pendidikan (Bandung, Pustaka Rahmat, Thn 2018) $\mathrm{HIm}, 34$
} 
10 Ahmad Yanuar Syauki1, Destri Astrianingsih², Nadiyya Khoiriyah³, Peranan Model

Pembelajaran Kooperatif Tipe Picture and Picture Terhadap Keterampilan

mengorganisasi literatur adalah mencari ide, tujuan umum, dan kesimpulan dari literatur dengan membaca abstrak, dan beberapa paragraf pendahuluan dan kesimpulan serta mengelompokan literatur berdasarkan ketegori tertentu.

2. Synthesize, yaitu menyatukan hasil organisasi literatur menjadi suatu ringkasan agar menjadi satu kesatuan yang baik, dengan mencari antar keterkaitan antar literatur.

3. Identify, yaitu mengidentifikasi masalahmasalah dalam literatur. Masalah yang dimaksud adalah masalah yang dianggap sangat penting untuk dianalisis guna mendapatkan suatu tulisan yang menarik untuk dibaca.

4. Formulate, yaitu merumuskan pertanyaan yang membutuhkan penelitian lebih lanjut.

Adapun teknik pengumpulan data yang digunakan oleh penulis dalam penelitian ini disesuaikan dengan fokus dan tujuan penelitian, yaitu :

\section{a. Studi Pustaka}

Penelitian yang dilakukan oleh peneliti dengan mengumpulkan sejumlah bukubuku, buku tersebut dianggap sebagai sumber data yang akan diperoleh dan dianalisis seperti banyak dilakukan oleh ahli sejarah, penelitian yang dilakukan dengan menggunakan studi pustaka dapat memperoleh informasi tentang teknikteknik penelitian yang diharapkan.

c. Dokumentasi
Yaitu berupa buku-buku terkait, media elektronik, karya ilmiah, jurnal serta skripsi terdahulu yang dapat dipertanggung jawabkan.

\section{HASIL DAN PEMBAHASAN}

\section{A. Deskripsi Objek Penelitian}

Pada penelitian ini objek penelitian diambil dari sumber data skunder, obyek penelitiannya di gali melalui beragam informasi kepustakaan baik itu buku, ensiklopedia, jurnal ilmiah, koran, majalah, dan dokumen-dokumen lainnya yang berhubungan dengan model pembelajaran picture and picture. Yang diambil dari bukubuku terkait jurnal dan penelitian yang relevan.

Objek penelitian dari sumber buku atau literatur diantaranya:

1. H. Isjoni, Pembelajaran Kooperatif, (Bandung: Putaka Pelajar, 2013)

2. Moch. Agus Krisno Budiyanto, Sintaks 45 Model Pembelajaran, (Malang, Universitas Muhammadiah Malang 2019)

3. Retno Purwandari, Buku Pintar Bahasa Indonesia), (Jakarta: Permendiknas, 2009)

4. Azhar Arsyad, M.A. Media Pembelajaran, (Jakarta, Rajawali Pres, Tahun 2017)

Adapun identitas objek sumber hasil penelitian yang dirujuk pada penelitian ini adalah:

1. N1 Jurnal: Heriyanto (2014) Judul, Penggunaan Model Pembelajaran 
11 Ahmad Yanuar Syauki, Destri Astrianingsih², Nadiyya Khoiriyah³, Peranan Model

Pembelajaran Kooperatif Tipe Picture and Picture Terhadap Keterampilan

Kooperatif Tipe Picture and Picture

Untuk Meningkatkan Kemampuan Siswa Menulis Karangan.

2. N2 Jurnal: Tati Fauziah \& Yoserizal Bermawi (2014) Judul, Penerapan Model Kooperatif Tipe Picture and Picture Pada Materi Peningkatan Sejarah Di SD Negeri Banda Aceh.

3. N3 Jurnal: W.Suwarni . Judul, Upaya Meningkatkan Keterampilan Menulis Melalui Model Pembelajaran Picture and Picture Siswa Kelas II SDN Gunung Picung Kecamatan Pamijahan.

Adapun gambaran umum model pembelajaran picture and picture adalah suatu model pembelajaran yang menggunakan gambar dan dipasangkan/diurutkan menjadi urutan logis. Model pembelajaran ini mengandalkan gambar sebagai mediadalam proses pembelajaran, dimana dalam prosesnya setiap siswa diberikan sebuah gambar (soal) lalu secepatnya merangkai kata demi kata agar menjadi sebuah ,paragraf , pada penerapan model pembelajaran ini siswa diajak aktif selama proses kegiatan berlangsung.

Indikator keterampilan menulis paragraf dalam penelitian ini yaitu:

a. Anak mampu menulis sebuah paragraf

$b$. Anak mampu menggunakan model tipe picture and picture

Pembelajaran keterampilan menulis paragraf akan menarik dengan model pembelajaran picture and picture sehingga perkembangan kognitif siswa dalam keterampilan menulis paragraf akan berkembang secara optimal.

\section{B. Hasil Penelitian}

Berdasarkan hasil penelitian dari berbagai sumber dari jurnal yang membahas tentang Penggunan model pembelajaran kooperatif tipe picture and picture untuk meningkatkan perkembangan kognitif anak dalam keterampilan menulis paragraf. Peneliti mengambil penelitian ilmiah terdahulu untuk dijadikan sebagai sumber study literatur atau kepustakaan (Library Research), yaitu 3 jurnal.

\section{Analisis identitas sumber yang dirujuk}

Data ini diambil berdasarkan rangkuman dari hasil penelitian-penelitian terkait terdahulu yang berkaitan dengan model pembelajaran picture and picture untuk meningkatkan perkembangan kognitif anak dalam keterampilan menulis paragraf, data tersebut diambil dan dilaporkan kembali untuk mengetahui seberapa besar keberhasilan penggunaan model pembelajaran picture and picture terhadap peningkatan keterampilan menulis paragraf pada siswa SD, dengan cara deskriftif kualitatif.

Adapun identitas sumber yang dirujuk dalam penelitian ini adalah sebagai berikut : 
12 Ahmad Yanuar Syauki, Destri Astrianingsih², Nadiyya Khoiriyah33, Peranan Model

Pembelajaran Kooperatif Tipe Picture and Picture Terhadap Keterampilan

Tabel daftar hasil penelitian

\begin{tabular}{|c|c|c|c|c|c|c|}
\hline $\mathrm{N}$ & Kode Data & 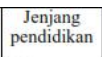 & $\begin{array}{c}\text { Kelompok } \\
\text { /kelas }\end{array}$ & \begin{tabular}{|l|} 
Penulis \\
\end{tabular} & Sumber & Judul \\
\hline 1 & $\mathrm{N1}$ & SD & IV & Heriyanto & \begin{tabular}{|l|} 
Universitas \\
Muhanmadiyya \\
h Sidoarjo. \\
Pedagogia Jurnal \\
Pendidikan, Vol. \\
3,No. 1, Febraari \\
2014: halaman \\
10-18 \\
ISSN: 2548- \\
2254 (online) \\
ISSN: 2089- \\
3833 (print)
\end{tabular} & 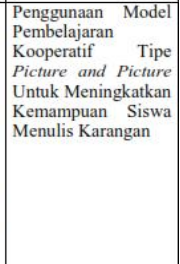 \\
\hline 2 & N2 & SD & IV & \begin{tabular}{|l|} 
Tati \\
Fauziah \& \\
Yoserizal \\
Bermawi
\end{tabular} & 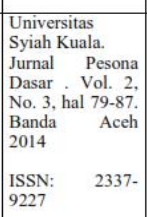 & $\begin{array}{|lr|}\text { Penerapan } & \text { Model } \\
\text { Kooperatif } & \text { Tipe } \\
\text { Picture and } & \text { Picture } \\
\text { Pada } & \text { Materi } \\
\text { Peningkatan } & \text { Sejarah } \\
\text { Di SD Negeri Banda } \\
\text { Aceh }\end{array}$ \\
\hline 3 & N3 & SD & II & $\begin{array}{l}\begin{array}{l}\text { W.Suwar } \\
\text { ni }\end{array} \\
\text {. }\end{array}$ & 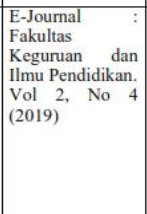 & 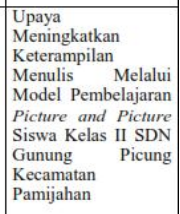 \\
\hline
\end{tabular}

Hasil peningkatan dari peranan model pembelajaran kooperatif tipe picture and picture terhadap keterampilan menulis paragraf siswa sd :

Tabel

Presentase penerapan model pembelajaran kooperatif tipe picture and picture terhadap keterampilan menulis paragraf siswa SD

\begin{tabular}{|c|c|c|c|c|}
\hline No & Kode & \multicolumn{2}{|c|}{ Hasil Persentasi } & Peningkatan \\
\cline { 3 - 4 } & Data & $\begin{array}{c}\text { Skor } \\
\text { Pretes }\end{array}$ & $\begin{array}{c}\text { Skor } \\
\text { Postes }\end{array}$ & \\
\hline 1 & N1 & $55 \%$ & $88 \%$ & $33 \%$ \\
\hline 2 & N2 & $50 \%$ & $82,33 \%$ & $81,83 \%$ \\
\hline 3 & N3 & $53 \%$ & $86,11 \%$ & $49,94 \%$ \\
\hline
\end{tabular}

Berdasarkan table di atas menyebutkan bahwa adanya peningkatan keterampilan menulis paragraf dengan menggunakan model pembelajraan picture and picture dilihat dari data $\mathrm{N} 1$ pretes $55 \%$ meningkat menjadi $88 \%$ sehingga mengalami peningkatan yang diperoleh sebanyak $33 \%$.

Data N2 pretes $50 \%$ menjadi $82,33 \%$ sehingga mengalami peningkatan yang diperoleh sebanyak $81,83 \%$ dan data N3 pretes $53 \%$ menjadi $88 \%$ sehingga terjadi peningkatan sebanyak $35 \%$.

Sehingga presentasi nilai rata-rata dari data yang di peroleh mulai dari kode data N1,N2 dan N3 menunjukkan peningkatan yang signifikan yaitu dari sebelum menggunakan model pembelajaran picture and picture 52,66\% sesudah menggunakan model pembelajaran picture and picture menjadi $86,11 \%$, dengan nilai rata-rata peningkatan $49,94 \%$.

\section{PENUTUP}

\section{Simpulan}

Terbukti telah terjadi peningkatan jumlah presentasi yang cukup signifikan pada setiap penelitian yang telah dilaksanakan oleh penelitian sebelumnya dengan jumah rata-rata peningkatan dari tiga jurnal yang dirujuk yaitu nilai awal pretes $52,66 \%$ dan meningkat menjadi $86,11 \%$ pada skor postes dengan rata-rata peningkatan dari peneliatian terdahulu yaitu $49,94 \%$.

Ternyata dengan menggunakan model pembelajaran picture and picture dapat meningkatkan keterampilan menulis paragraf terhadap anak sekolah dasar, dimana kepanpun keterampilan menulis paragraf merupakan kemampuan dasar 
13 Ahmad Yanuar Syauki1, Destri Astrianingsih², Nadiyya Khoiriyah³, Peranan Model

Pembelajaran Kooperatif Tipe Picture and Picture Terhadap Keterampilan

berbahasa, sehingga dapat membantu mempermudah menerima pembelajran untuk melanjutkan kejenjang yang lebih tinggi.

\section{Saran}

Berdasarkan hasil penelitian dengan menggunakan model pembelajaran picture and picture terhadap keterampilan menulis paragraf maka peneliti mengajukan beberapa saran diantaranya :

1. Bagi guru, disarankan agar menggunakan media pembelajaran denganmeggunakan media gambar untuk meningkatkan keterampilan menulisparagraf pada anak sekolah dasar dan meningkatkan kompetensi serta membekalidiri dengan pengetahuan luas, karena sesungguhnya kompetensi guru sangat mempengaruhi keberhasilan proses belajar mengajar yang pada akhirnya akan menghasilkan anak yang berprestasi, berakhlakul karimah, dan berbudi pekerti luhur. Sehingga berdampak positif pada perkembangan dan kemajuan sekolah.

2. Bagi pihak sekolah, disarankan untuk lebih memperhatikan fasilitas dan melakkan koordinasi antar lembaga di lingkungan sekolah karena sangat menunjang bagi perkembangan siswa.

3. Bagi Peneliti selanjutnya yang ingin mengadakan penelitian lebih lanjut tantangmetode pembelajaran dengan menggunakan model pembelajaran picture and picture pada siswa sekolah dasardisarankan untuk lebih mendalami lagi, karena masih banyak hal menarik yang dapat diperoleh dengan menggunakan media pembelajaran ini.

\section{DAFTAR PUSTAKA}

Alek A Dan Ahmad. 2020. Bahasa Indonesia Untuk Perguruan Tinggi, Jakarta:Kharisma Putra Utama.

Agus N Cahyono. 2013. Panduan Aplikasi Teori-Teori Belajar Mengajar Teraktual Dan Terpopuler, Yogyakarta: Diva Press.

Arsyad Azhar. 2017. Media Pembelajaran, Jakarta, Rajawali Pres.

Aldi Ulil, 2014. "Penerapan Model Pembelajaran Picture And Picture Untuk Meningkatkan Sikap Toleran Terhadap Keberagaman Siswa”, Semarang: Jurnal Ilmiah Ppkn IKIP.

Depdiknas. 2009. Sistem Pendidikan Nasional. Jakarta: Depdiknas.

Diantama Suarifqi, 2018. Metode Penelitian Pendidikan, Bandung, Pustaka Rahmat.

Eggen Paul. Don Kauchak, 2012. Strategi Dan Model Pembelajaran. Mengajarkan Konten Dan Keterampilan Berpikir, (Jakarta: PT. Indeks).

Fauziah, Tati. 2014. Judul Jurnal: Penerapan Model Kooperatif Tipe Picture And Picture Pada Materi Peningkatan Sejarah Di SD Negeri Banda Aceh. Universitas Syiah Kuala, Jurnal Pesona Dasar. 
$14 \mid$ Ahmad Yanuar Syauki1, Destri Astrianingsih², Nadiyya Khoiriyah³, Peranan Model

Pembelajaran Kooperatif Tipe Picture and Picture Terhadap Keterampilan

Hamdani, 2010. Strategi Belajar Mengajar,

Bandung: Pustaka Setia.

Hamzah Amir. 2020. Metode Penelitian

Kepustakaan Library Reseratch,

Malang: Literasi Nusantara. 
15 Ahmad Yanuar Syauki1, Destri Astrianingsih², Nadiyya Khoiriyah³, Peranan Model

Pembelajaran Kooperatif Tipe Picture and Picture Terhadap Keterampilan

Hendry, Tarigan. 1986. Menulis Sebagai

Suatu Keterampilan Berbahasa, Bandung: Angkasa.

Huda Miftahul. 2014. Model-Model Pengajaran Dan Pembelajaran, Yogyakarta: Pustaka Pelajar.

Huda Miftahul. 2015. Cooperatif Learning: Metode, Teknik, Struktur, Dan Model Penerapan, Yogyakarta: Pustaka Pelajar.

Heriyanto, 2014. Judul Jurnal: Penggunaan Model Pembelajaran Kooperatif Tipe Picture And Picture Untuk Meningkatkan Kemampuan Siswa Menulis Karangan, Universitas Muhammadiah Sidoarjo, Pedagogia Jurnal Pendidikan.

Isah Cahyani, Khodijah. 2007. Kemampuan Berbahasa Indonesia Di SD, Bandung: Upi Press.

Masito, Laksmi Dewi, Tt. Strategi Pembelajaran, Jakrata: Direktorat Jendral Pendidikan Islam Departemen Agama Rebulik Indonesia.

Miftahul, Asyifa. 2017. Meningkatkan Keterampilan Menulis Karangan Narasi Melalui Model Pwim (Picture Word Inductive Model) Siswa Kelas IVB SD Negeri Ketib Kecamatan Sumedang Utara Kabupaten Sumedang. Jurnal Pena Ilmiah: Vol.2, No 1).

Moch. Agus Krisno Budiyanto. 2019. Sintaks 45 Model Pembelajaran, Malang, Universitas Muhammadiah Malang. Permendikbud. 2013. Kurikulum 2013 No. 67.
Resmini, Novi, Dkk. 2006. Membaca Dan Menulis Di SD Teori Dan Pengajaran, Bandung: Upi Press.

Rusman. 2013. Model-Model Pembelajaran Mengembangkan Profesionalisme Guru, Jakarata:PT. Raja Grafindo, Persada.

Sanjaya Wina. 2008. Strategi Pembelajaran Berorentasi Standar Proses

Pendidikan, Jakarta:Kencana

Perdana Media Grup.

Siregar Eveline. 2020. Teori Belajar Dan

Pembelajaran, Bogor: Gladii Indonesia.

Suladi. 2015. Paragraph, Jakarta: Pusat Pembinaan Badan Pengembangan Dan Pembinaan Bahasa Kementrian Pendidikan Dan Kebudayaan.

Susanto. Ahmad. 2013. Teori Belajar dan Pembelajaran di Sekolah Dasar. Jakarta: Prenadamedia Group. Susanto Ahmad. 2014. Pengembangan Pembelajaran IPS, Jakarta: Prenada Media Group.

Suprijono, Agus. 2012. Metode Dan ModelModel Mengajar, Bandung, Alfabeta. Suwarni, W. 2019. Judul jurnal: Upaya Meningkatkan Keterampilan Menulis Melalui Model Pembelajaran Picture And Picture Siswa Kelas 2 SD Negeri Gunung Picung Kecamatan Pamijahan. E-Journal Fakultas Perguruan Dan Ilmu Pendidikan.

Trianto. 2009. Mendisain Model Pembelajaran Inovatif-Progresif. Konsep, Landasan, Dan Implementasinya Pada Kurikulum Tingkat Satuan Pendidikan (Ktsp), 
16|Ahmad Yanuar Syauki, Destri Astrianingsih², Nadiyya Khoiriyah³, Peranan Model

Pembelajaran Kooperatif Tipe Picture and Picture Terhadap Keterampilan

$$
\text { Jakarta:Charisma Putra }
$$

Utama.

Widianto, Eko. 2015 Peningkatan

Keterampilan Membaca Teks

Klasifikasi Menggunakan Metode

Sq3r Dengan Media Gambar. Jurnal

Pendidikan Bahasa Dan Sastra

Indonesia.

Wiyanto Asul. 2006. Trampil Menulis Paragraph, Jakarta: PT Grasindo.

Zed Mestika. 2014. Metode Penelitian

Kepustakaan, Jakarta, Yayasan

Pustaka, Obor Indonesia. 